\title{
Slaughter practices of different faiths in different countries
}

\author{
Zeiad Amjad Aghwan ${ }^{1 *}$ and Joe Mac Regenstein ${ }^{2}$ \\ ${ }^{1}$ Halalan Thayyiban Research Centre, Universiti Islam Sultan Sharif Ali, Simpang 347, Jalan Pasar, Baharu, Gadong BE 1310, Negara \\ Brunei Darussalam \\ ${ }^{2}$ Department of Food Science, Cornell University, Ithaca, NY 14853-7201, USA
}

\section{Abstract}

This paper reviews many aspects of ritual and traditional slaughter methods used to produce meat for human consumption in different countries. Undoubtedly, meat is an important source of nutrients that are essential for human health. The global meat market has become increasingly interested in Islamic halal and Jewish kosher slaughter, in particular because of potential market opportunities. The requirement for unstunned slaughter or reversible pre-slaughter stunning makes religiously-based methods of animal slaughter unique. This study suggests a simple framework for a halal and tayyib meat supply chain for the Muslim community that also maintains meat quality and wholesomeness from farm to table as a model for the religious slaughter of animals.

Keywords: Halal, Jhatka, Kosher, Non-stunned slaughter, Reversible stunning

\section{Background}

Modern industrial production of high-quality meat must meet the diverse demands of consumer groups and food safety regulators. Yet, early societies also addressed the slaughter, preparation, and production of meat and may provide valuable insights. In Greek and Roman times it seems that the authorities already managed the slaughter process and removed unhealthy meat from the human food supply [1]. One of the earliest indications of meat inspection is found in Hebrew Scripture in the book of Deuteronomy (the fifth book of the Hebrew Scriptures and the last book of the fundamental Jewish text known as the Torah) [2]. Many of the controls on the slaughter procedure were implemented through religious prohibitions and rituals.

Accepting religiously that animals may be slaughtered, then how should this be done? The methods used have varied among different cultures and faiths, and over time they have evolved with advances in technology. Clottey [3] reported that the four methods that are most prevalent internationally are halal (Muslim), kosher (Jewish), industrial (stunned) slaughter, and Jhatka (Sheik, the least used of the four). For Jews and Muslims specifically, there are significant religious requirements for the slaughter of animals that have been observed from the earliest days of these faiths. These requirements are embodied in the Islamic concepts of halal or lawfulness and of tayyib, permitted and wholesome, which are part of Islamic law (Sheriah, derived from the Qur'an and Hadiths (practices and sayings of the Prophet Muhammad (peace be upon him [PBUH]). Furthermore, the Jewish concept of kosher (religiously pure) foods is found in the laws and regulations of kashrut (Jewish dietary law) [4]. These concepts are central to the commercial production of meat for these communities [4,5]. In both cases it seems that currently demand exceeds supply and the demand is growing

Received: Dec 26,2018 Revised: May 3, 2019 Accepted: May 15, 2019

"Corresponding author: Zeiad Amjad Aghwan, Halalan Thayyiban Research Centre, Universiti Islam Sultan Sharif Ali, Simpang 347, Jalan Pasar, Baharu, Gadong BE 1310, Negara Brunei Darussalam.

Tel: +673-2462000 E-mail: zeiadamjad@yahoo.com

This is an Open Access article distributed under the terms of the Creative Commons Attribution Non-Commercial License (http://creativecommons.org/licenses/by$\mathrm{nc} / 4.0 /$ ) which permits unrestricted non-commercial use, distribution, and reproduction in any medium, provided the original work is properly cited.

Copyright (C) 2019 Korean Society of Animal Science and Technology. 


\section{JAST}

[4]. Bleeding of carcasses to maximize blood loss is a requirement of halal slaughter.This practice religiously purifies the animal making it good and wholesome for human consumption [6]. Regardless of potential issues of pain, halal slaughter methods practiced in different countries are compatible with halal requirements in term of blood loss [7]. It is a vital step in the production of halal and tayyib (acceptable and wholesome) meat for Muslim consumption [8].

Shechita or religious slaughter of mammals and birds must be done in accordance with the Jewish dietary laws [5]. The animal must be kosher (ruminants with split hooves that masticate their cud, or domestic birds that are not birds of prey). The act of slaughter is done by using a very sharp nick-free knife across the animal's neck (below the glottis) and allowing the blood to drain out.

Pre-slaughter stunning, the practice of electrically, mechanically or chemically inducing unconsciousness in an animal before slaughter is normally used for conventional commercial slaughter [9]. Stunning of animal before slaughter is an obligatory procedure in the USA, UK, EU, Australia, New Zealand, South Africa, Brazil and East Asia countries. It supposedly aims to lessen the distress and pain of animals through the use of appropriately accepted stunning methods, based on scientific knowledge and practical experience [9]. China, the world's biggest pork producer and consumer, also uses pre-slaughter stunning of commercially farmed animals.

According to the Manusmriti, a Hindu-law book, slaughtering of animals with the exception of rituals or for food was strongly forbidden, with similar blame to the slaughterer, butcher, and consumer. The law book discussed sacramental sacrifices of particular animals and the consuming of their meat under certain circumstances. Additionally, Hindus believe sympathy for animals is one of the best virtues and a sign of spiritual value [10]. Jhatka is a technique that allows one to kill an animal (beheading the animal by a single blow to the backbone side of the neck to cause sudden death allowing it no time to feel or realize any pain) according to Hindu law to produce meat to be consumed by Hindus. According to India Curry [10], there is no religious tenet involved with Jhatka.

Africa is a continent that includes an array of nations and cultures, some which are practicing halal (Muslim) and kosher (Jews). Other communities use other forms of un-stunned slaughter, which is not governed by Western religious rules. Additionally, pre-slaughter stunning of animals prior to "sticking" is also accepted by some African communities. Moreover, there are numerous strong African traditions for how to slaughter animals that are still followed. The main requirement for all these faiths is that the animal should be alive and fully conscious for the slaughter.

There are many slaughter methods used throughout the world and these are based on industrial (a techno-scientific ideology), cultural and religious beliefs. Therefore, this paper reviews the relevant aspects of religious and industrial slaughter methods in different countries around the world as the main step in producing wholesome meat fit for human consumption.

\section{The significance of meat for human health}

Meat is the palatable flesh and organs of livestock, poultry, game and fish that are appropriate for human consumption. It is an important source of essential nutrients such as protein (which is high in both quality (from a human perspective) and quantity), fat, vitamins and minerals. These nutrients are essential for human health; this accounts for the fact that meat consistently appears as a major component in diets across the globe. Additionally, it has been reported that the content of some essential nutrient in meat such as long chain n-3 polyunsaturated fatty acids (PUFA) [11], selenium and iodine [12] can be improved through increasing their supplementation in animal feed. Nevertheless, meat (particularly red meat) is comparatively high in cholesterol, saturated fatty acids and sodium in processed meats. High saturated fat and possibly cholesterol is of special nutritional concern in the human population in the light of their proposed role in increasing plasma low density lipoprotein (LDL) cholesterol, a main risk factor for cardiovascular diseases in human $[13,14]$. In addition, excessive sodium intake could lead to high blood pressure and may increase the risk of heart failure and stroke. Ruusunen and Puolanne, [15] reported that processed meats had significantly higher sodium content than unprocessed fresh meat. Recently, the Superior Health Council [16] and the World Cancer Research Fund/American Institute for Cancer Research [17] have recommended limiting red meat consumption to 100 grams per day and a maximum weekly intakes of processed red meat to 500 grams. Norat et al. [18] and Cross et al. [19] reported that minimizing consumption of processed red meat products may reduce the risk of colorectal cancer (CRC). CRC is the main form of cancer mortality in European nonsmokers [20]. Furthermore, moderate intake of lean red meat may positively affect nutrient levels, and thus improve long term human health.

Recently, evidence from human studies, animal model studies, and use of in vitro models showed that there are inconsistent relations between red and processed meat intake and CRC [21]. However, the working groups of the International Agency for Research on Cancer (IARC) categorized red meat as "possibly cancer-causing to individuals" and processed meat as "cancer-causing to individuals" with regard to CRC [22], although this organization is often alone in its recommendations. Oostindjer et al. [21] suggested that modify meat composition through animal feeding and breeding and adding phytochemicals to improve processed meat may be helpful to reduce the risk of CRC and cardiovascular diseases. This could be achieved by further collaboration between 
the academics, the meat industry and public health authorities.

\section{Halal slaughter}

Dhabiha(ذَبيحة)represents the permitted techniques for the halal slaughter of all meat animals, birds (also game that is hunted or trapped) excluding halal acceptable seafood that is fished according to Islamic laws. For halal acceptable animals and birds, the procedure for slaughtering animals includes using a well-sharpened knife to make a swift, deep incision that cuts the front of the esophagus, trachea, the jugular veins and the carotid arteries (Fig. 1). The rule includes lining up the head of the animal to be slaughtered in the direction of the Qiblah (facing towards Mecca). The performance of dhabiha is a religious act. Furthermore, approved animals should be slaughtered upon pronouncement of the Islamic invocation 'Bismillah Allahu Akbar' (in the Name of Allah, Allah is the greatest). This is ideal, but Bismillah alone is also permitted by some, and some want the three words repeated for every bird or animal. The features of halal slaughter comprise:

- Slaughtering process should be done only on religiously permitted animals (Al-Baqarah 2:173).

- Animals should be given a proper rest and water before slaughter.

- The welfare of the animal is of paramount importance from the farm to the point of slaughter.

- The animal should be restrained, once the slaughter man is ready, with a comfortable position before and during slaughter. The purpose of effectively restraining an animal is to limit reactions and movement. So the stunning or slaughtering can be precise, rapid and more efficient with the least distress to the animal. Movement in the restrainer should be restricted by a body lift that just touches the animal to limit movement and a head restrainer to allow the neck and throat to be fully exposed for cutting but supporting the head to minimize head movement.

- The slaughter process should be done by an observant and practicing Muslim. The meat from animals slaughtered by the "People of the Book" is allowed to be consumed by Muslims (Al-Maida 5:5).

- Slaughtering should be carried out using a sharp knife of adequate length (a straight knife two times the diameter of the neck is currently recommended [24]) to keep the end of the knife outside the neck. A short knife results in intense pain due to the digging of the end of the blade into the throat [25]. It is better to slaughter the animal with a single swipe and avoid sawing. The cut must be made from the anterior side, keeping the spinal cord intact, and not from the backbone side. Biological tools such as bones, nails, and teeth should not be used for slaughtering. In a Hadith by Bukhari, Prophet Muhammad (PBUH) preached when he said: "Use everything to slaughter which allows blood to flow, with the exception of teeth and nails all else is permissible".

- The knife must not be sharpened in the presence of an animal, and should be cleaned from blood and impurities using flowing water after each cut.

- The cut should be deep enough to ensure both arteries and jugular vessels are cut and the blood is flowing freely out of carcass, as blood is forbidden for Muslim consumption (Al-An'am 6:145), so the animal will die within the shortest time.

- Animals must not be allowed to see other animals being slaughtered (at the point of slaughtering).

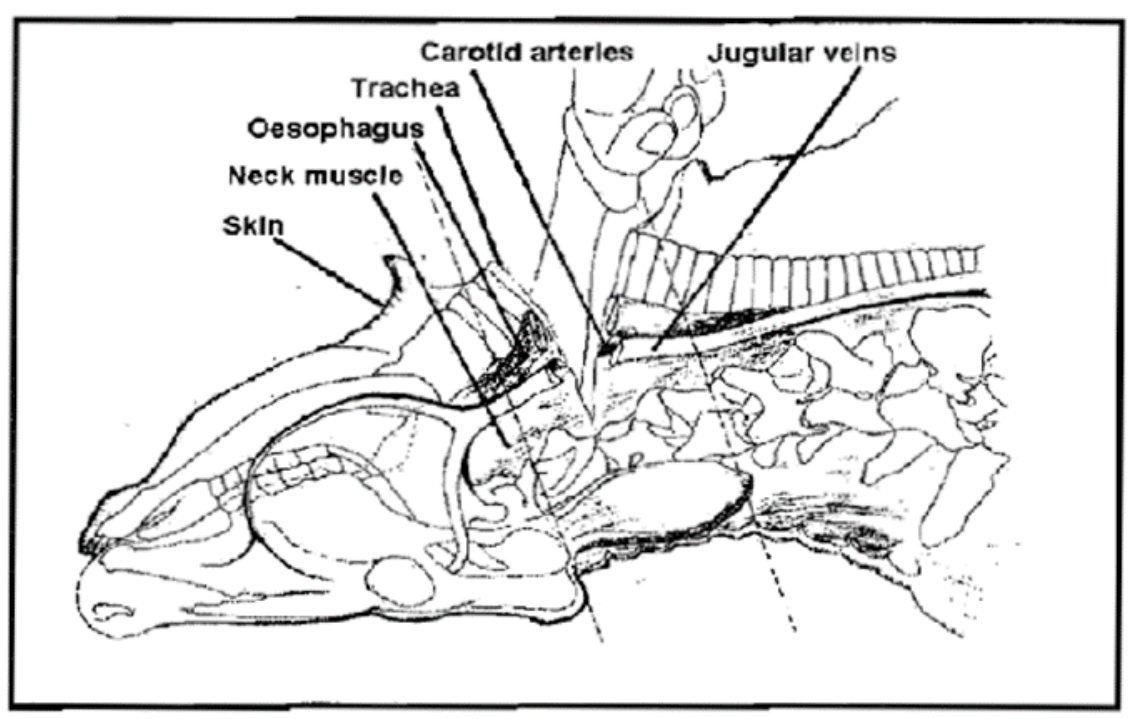

Fig. 1. Halal method of slaughtering cattle. Adapted from Department of Standards Malaysia [23]. 


\section{JAST}

- The animal should be kept restrained after the neck cut and not moved nor any dressing or other procedures started until the animal is dead.

The Qur'an contains a number of verses referencing dhabiha, and Allah reminds the believers to mention His name at the time of slaughtering, such as:

"That they may witness benefits for themselves and mention the name of Allah on known days over what He has provided for them of [sacrificial] animals. So eat of them and feed the miserable and poor."

(Al-hajj 22:28).

"For you the animals marked for sacrifice are benefits for a specified term; then their place of sacrifice is at the ancient House."

(Al-hajj 22:33).

"And the camels and cattle We have appointed for you as among the symbols of Allah; for you therein is good. So mention the name of Allah upon them when lined up [for sacrifice]; and when they are [lifeless] on their sides, then eat from them and feed the needy and the beggar. Thus have We subjected them to you that you may be grateful."

(Al-hajj 22:36).

"So eat of that [meat] upon which the name of Allah has been mentioned, if you are believers in His verses."

(Al-An'am 6:118).

In a Hadith by Bukhari, Prophet Muhammad (PBUH) warned in a clear expression that he will fight those (Muslims) who do not practice slaughter as he does:

"I have been ordered to fight the people till they slaughter (animals) as we slaughter."

The halal slaughtering of domestic animals for food is a Muslim method of bleeding of animals based on Islamic Laws that cleanses an animal from blood and uncleanness, thus making it good and nutritious for human consumption. Usually, appearance, acceptability, cleanness and meat shelf life are affected negatively by incomplete bleeding of animals [26]. The holy Qur'an made reference to what is permitted and prohibited in terms of meat and food. Muslims deduce what is halal and haram from these and similar verses:

"Prohibited to you are dead animals, blood, the flesh of swine, and that which has been dedicated to other than Allah, and [those animals] killed by strangling or by a violent blow or by a head-long fall or by the goring of horns, and those from which a wild animal has eaten, except what you [are able to] slaughter [before its death], and those which are sacrificed on stone altars...."

(Al-Ma’idah5:3).

"Today, all good food is made lawful (halal) for you. The food of the people of the scripture is lawful for you, and your food is lawful for them."

(Al-Ma`idah5:5).

"And eat of what Allah has provided for you [which is] lawful (balalan) and good (tayyiban). And fear Allab in whom you are believers."

(Al-Ma’idah 5:88).

\section{Halal management and accreditation}

Halal management is the handling of all the tasks and activities required to determine and cover the halal integrity of a product from its place of origin to the point of purchase by a consumer [27]. The implementation of a halal management system will allow the production of authentic halal products and services for the consumer. The top management's responsibilities not only cover the financial parts, but also in providing enough manpower, a proper premise with appropriate processing capabilities, halal materials, and training of all personnel. According to the Department of Standards Malaysia [23], halal accreditation is the process of supervising halal certifiers as meeting minimum requirements designated by an accrediting agency to enhance economic, societal, and environmental prosperity.

Both the Department of Islamic Development Malaysia, JAKIM, [28] and the Humane Slaughter Association, HAS [29] believe that halal slaughter plants should have certifying agency officers who are knowledgeable monitor the slaughtering process. It is most important for the certifying bodies to have religious consultants/advisors to advise on issues related to proper slaughtering procedures and to provide prompt supervision of workers from the religious standpoint. However, these religious advisors should also have technologic and scientific knowledge so that they provide sound opinions and establish workable and appropriate guidelines. Both halal supervisors and slaughtermen should be observant Muslims, who know the rules and conditions set by Islam with regard to slaughtering. Slaughtermen should be educated and trained in halal slaughtering practices and be recommended by a local certifying body that knows the person. Training is the gaining of skills, notion, and attitude that results in better performance within the job environment. This training should include adequate information on hygienic laws, regulations, anatomical positions of the neck, animal stress physiology, and the appropriate equipment to be used for slaughter. A sufficient number of supervisors and slaughtermen should be employed in the slaughterhouses and meat processing 
plants. According to the Manual Procedure for Malaysia Halal Certification (Third Revision) 2014 [28], the slaughterman should be replaced after the slaughterer has reached a maximum of 3.000 birds or 25 ruminants at one time. Slaughterhouses must be licensed with a halal certificate from recognized Islamic authorities to ensure that they comply with the guidelines and regulations according to Islamic law to maintain halal integrity.

\section{Kosher slaughter}

Since the giving of the law at Mount Sinai, the Jewish religious scholars (rabbis) have interpreted, polished, and enacted the definition of Biblical kosher laws to protect the Jewish society from contravening any of the basic laws, and to explain how to deal with new matters and recently developed technologies. In the USA, Jewish consumers represent only 20\%-33\% of the most likely more than 10 million Americans who intentionally purchase kosher food. Muslims, Seventh Day Adventists, vegans and vegetarians are other consumers who find kosher products meeting their dietary needs [5]. There are three main issues that the kosher dietary laws (kashrus) deal with to determine which food are proper for Jews; (1) allowed animals; (2) the prohibition of blood; and (3) the prohibition of mixing milk and meat [4]. All foods and the equipment used to make them ready have to be defined as belong to one of four categories: meat (fleishig), dairy (milchig), neutral (parve), or unacceptable (treife) [30].

Shechita is the religious procedure of slaughtering of permitted (kosher) land animals (domestic animals that masticate their cud and have cloven hooves) and birds which have a stomach lining that can be removed from the rest of the gizzard (excluding predatory and scavenger birds) according to Jewish religious laws and tradition (Halacha) that originate from the Torah and the verbal law received by Moses as recorded in the Talmud [5]. Animals with one kosher trait such as camels, hares (appear to masticate their cud and do not have cloven hooves) and pigs (have cloven hooves but do not masticate their cud) are prohibited.

Similar to halal slaughter techniques, shechita is carried out without stunning. The esophagus, trachea, jugular veins and the carotid arteries of the animal are cut and its blood is allowed to flow out—again because blood contains impurities that render meat unsuitable for human consumption. Additionally, beheading is not permissible. According to Jewish law, the slaughter should be specifically done by a skilled ritual slaughter man (shochet) with a particular knife (chalef) which is very sharp with a straight blade (Fig. 2) that is no less than double the width of the neck of the animal to be slaughtered. The regulations for slaughter are very rigorous. The slaughter must done according to Jewish law following the highest criterion of current animal handling applications. Before the slaughter, the shochet both asks a blessing asking for

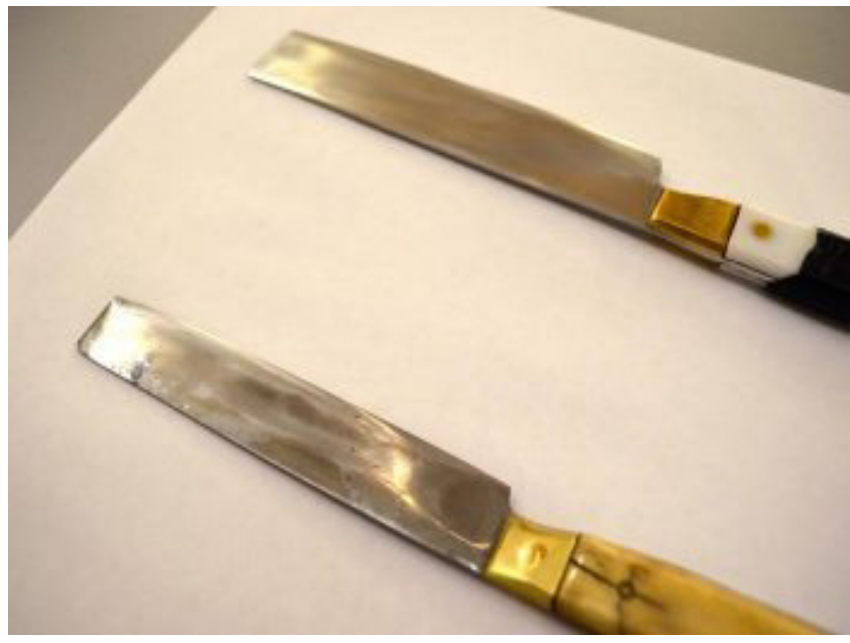

Fig. 2. Chicken chalefs for kosher slaughter. Adapted from Gross GA [31].

forgiveness for taking the life of a sentient being and inspects each animal carefully. The shochet checks the sharpness of the blade. After the cut is made, the shochet makes sure it was done properly. The shochet must also check the chalef once more to make sure that the blade was not scratched during the slaughter. If the knifeedge is scratched, the meat may not be consumed by Jews [5]. Additionally, Regenstein et al. [5] reported that the animal is considered not kosher (treife) if there are any problems with the cut or the knife. Indeed, the training of a shochet includes learning to avoid the five main forbidden practices include: pausing, pressing, piercing, tearing, and covering which may render the animal not kosher [32].

After slaughter, the internal visible organs are inspected for any blemishes by a skillful inspector (bodek). If the animal has any blemish, the animal will be rejected and becomes "treife". The lung is the most important organ that must always be inspected for injuries or lesions both while still in the lung cavity and again after it is removed from the animal. The bodek first removes any adhesions and thereafter blows up the lung and submerges it in water to decide that it is still intact. If the lungs are intact and had less than two lesions, the meat will refer to as glatt kosher. The word "glatt" in red meat conveys the message that a superlative standard is being used, while the word (Menhadrin) means that poultry and poultry products are produced with a stricter standard. Meat and poultry from kosher carcasses should then be prepared properly by taking off prohibited fats, arteries, veins, and blood. This process should be done by a specifically trained person (Menacker) and his team. To remove the prohibited blood, meat cuts (most probably front quarter cuts) and poultry will be immersed in cool water for half an hour. To draw out the blood, the immersed meat and poultry are then positioned in specific salting tables where they are salt- 


\section{JAST}

ed along all surfaces for one hour with coarse salt. The salt should be large enough that the crystals will not liquefy within one hour and should be small enough to allow full coverage of the meat. For the animal's heart, the process of immersing and salting must be done after opening the heart and removing all clotted blood. The liver cannot be immersed or salted because of its high blood content. The liver must be grilled until it is more than half cooked using dedicated equipment for this purpose. It is worth mentioning that the process of immersing and salting of the meat and poultry (melicha) must be done within $72 \mathrm{~h}$ of animal slaughter or the meat must be washed to keep it moist. Such washing may be done for a maximum of three times for non-glatt meat. It is not permitted for glatt meat [33].

\section{Pre-slaughter stunning}

For consumers outside the traditions of Islam and Judaism, pre-slaughter stunning of animals is a relatively unproblematic practice during slaughter of domestic animals such as ruminants (cattle, sheep, and goats), pigs, poultry, and ostriches. Current pre-slaughter stunning procedures such as mechanical stunning using captive bolt for cattle, electrical head only for sheep and goats, or gaseous for pigs and poultry are a common feature of industrial slaughter across countries such as the USA, UK, EU, Australia, New Zealand, South Africa, Brazil and East Asia countries [5]. The aim of stunning is to minimize the stress and pain of animals through the use of accepted stunning methods based on scientific knowledge and practical experience [9]. In a typical example of this type of slaughter, the stunned animal is suspended using its posterior legs so that its head hangs down. In sheep and goat, poultry, and ostriches, the neck is incised behind the jaw using a sharp knife. There are two common bleeding techniques used with cattle. The first, a full frontal cut across the throat to cut both the jugular and carotids, the vessels that supply most of the oxygenated blood to the head and brain. The second technique is called a chest stick; first the skin of the neck is opened with an approximately 45 $\mathrm{cm}$ longitudinal cut between jaw and brisket using a boning knife. To avoid carcass contamination, a second knife or bleeding stick is then used to cut all the major blood vessels as they come from the heart. With both techniques, it should be ensured that all blood vessels are cut and the blood is flowing freely so the animal will die within a short time. While in pigs, a bleeding stick is inserted into the breast to cut the jugular and carotids vessels.

\section{What is the Jhatka procedure?}

The Jhatka procedure is limited only to goats and sheep (Sikhs and Hindus believe that cattle are sacramental and therefore the consumption of beef is proscribed). Jhatka is the least applied religious form of slaughter worldwide and occurs much less frequently

\section{Slaughter practices of different faiths in different countries}

compared to halal and shechita [3]. There is no spiritual sacrament implicated with Jhatka. In the Sikh and Hindu observance, they do not believe that any ritual needs to be associated with the killing of an animal to give the flesh a spiritual morality [10]. According to Hindu law, Jhatka is a technique for slaughtering an animal for meat to be consumed by Hindus. In the procedure, the head of the animal is attached to a stable column and the posterior legs are stretched out in the opposite direction. The animal is beheaded from the backbone side with a single stroke of a sword or axe. This will cause a sudden death of the animal because the spinal cord is cut, and the circulation of blood to the brain has been immediately stopped, resulting in brain failure within seconds. Thus, the animal will not feel or realize any pain. For this reason, this procedure is considered to cause the minimal pain and suffering to the animal compared to other procedures [10]. Thereafter, the animal is dressed to be ready for consumption. Even though Jhatka meat is quite common in Hindu areas where it is in demand, halal and kosher meat are far more familiar in the global market. In India, many Jhatka meat shops are available, with numerous by-laws requesting shops to demonstrate clearly that the meat put up for sale is Jhatka. However, Hubbert et al. [34] reported that at some time in the past, Jhatka meat was not widely available in the United Kingdome while nowadays Jhatka meat has become more available.

\section{Animal restraint}

One of the main animal welfare issues during stunning and/or slaughter without stunning is the stress of the restraint [35-38]. It is important that governments, researchers, animal welfare groups, and large meat purchasers strive to develop and use more humane methods to decrease animal distress and pain that are consistent with present religious and secular requirements with respect to animal slaughter. This could be achieved using improved restrainer systems for handling animals to ensure better treatment for all kinds of animals to be stunned or slaughtered. Grandin [25] reported that the animal's reaction to the restraint procedure and to the throat cut are two major welfare issues when religious slaughter is done. Stress produced by overly tight restraint may hide the reactions to the throat cut. Aghwan et al. [35] mentioned that efficient restraint during slaughtering or stunning could be achieved by using good equipment and well trained personnel which will minimize the pain and distress of the animal.

All livestock subjected to conventional slaughter are obliged to stun the animal so it becomes unconscious whilst they are positioned in a stunning box or in a restraint device. An interesting report of Velarde et al. [38] reviews recent methods for restraint during halal and shechita slaughter of cattle, sheep, goats and poultry in Belgium, Germany, Italy, the Netherlands, Spain, the 
UK, Turkey, and Australia. Four restraining positions were used for cattle; turned $45^{\circ}$, turned on their sides $\left(90^{\circ}\right)$, turned on their backs $\left(180^{\circ}\right)$, and upright. Three restraining methods are used for sheep and goats; hoisted before neck cutting, placed manually on their sides, and upright. Three restraining methods are used for poultry; hoisting before neck cutting, no restraint (sitting on a belt for gas stunning), and shackling for electrical water bath stunning. The team concluded that the quality of slaughter that may have negative effects on animal welfare are not only dependent on the restraint system and the stunning system (when used), but also on pre-slaughter handling and the competence of the operator engaged in the slaughter technique. Results of this work could be a basis for future work to study the effect of restraining methods on animal welfare before and during religious slaughter using competent operators, the same tools such as knives and equipment, and in the same environment.

In the USA, religious slaughter is exempted from the Humane Slaughter Act where stunning is not obligatory for halal and shechita slaughter. It has also been declared humane by the same legislative act. Grandin [25] reported that the large plants in the USA carry out kosher slaughter of cattle using an upright restrainer. However, a few smaller plants are still using the stressful procedure of restraint by shackling and hoisting of completely sensible animals (which is lawful in the USA for religious slaughter) by hanging animals upside down using a chain tied to their ankle. This is mostly with sheep and goats and not cattle. This is because it is cheaper and their customers have not request that using this cruel method be stopped since they seem to have little concern about animal handling. The best way to halt the shackling and hoisting method is to instruct the meat retailers and urge consumers to apply pressure to improve handling during religious slaughter [25]. A report from the Shamayim V'Aretz Institute entitled, "Say No to Shackle and Hoist", showed that in South America, the majority of slaughterhouses use a "shackle and hoist" method to produce kosher meat where the animal is dragged up and suspended by one of his hind legs on an assembly rail chain to turn the animal upside down, and then dropped down to the casting table before cutting its throat. Grandin [25] reported that the shackle and hoist restraint method causes a huge suffering of the animals and is also not safe for the workers.

Effective restraint means the animal can be held firmly without inflicting pain or distress. The main goal of efficiently restraining an animal is to restrict their motion. So the action of stunning or slaughtering can be more accurate, rapid, and effective with a minimal suffering to the animal. However, the process of being restraint can be itself distressing. There are some general principles that should be followed that may limit pain and distress of the animal; (1) the operators carrying out the restraint should be properly trained, they need to react quickly and appropriately as each animal responds differently; (2) no animal should be restrained until those who are going to stun or slaughter are ready; (3) once the animal is restrained it should be stunned or slaughtered immediately, excessive struggling and vocalization are indicators of excessive pressure or pain; (4) developing and using a simple performance scoring system when restraining animals can help to improve and maintain standards, large cattle should always be individually confined for stunning; (5) it is essential that the restraint devices be properly designed to prevent excessive forward, backward, and sideways movement; (6) devices could be installed within the box to position and control the movement of the body and allow the restraint of animals of different sizes; (7) to achieve minimal struggling and no vocalization, the restraint devices should be properly operated to prevent the use of excessive pressure that might cause pain, and should be applied carefully with no pinch points and with minimum amount of time; (8) boxes may also be fitted with mechanical devices such as head restraints and neck yokes so they can be used to position the head for more accurate stunning or the neck for accurate slaughter; (9) there should be good non-slip floors so that animals do not fall, and no sharp edges that would harm animals so the animals can be led or driven easily into them with no need for electrical prodding; and (10) the restraint devices must be maintained to reduce noise from air hissing and trunking metal and operated to apply even pressure, no jerking or rapid movements which might alarm or injure an animal.

\section{Simple structure of the halal and tayyib meat supply chain} If the halal and tayyib meat supply chain is understood (Fig. 3), then it is important to acknowledge the consumers as the chain's end. Generally producers and wholesalers need to develop optimize procedures to stay competitive by reaching the largest number of consumers with the least expensive product. The central aim of the halal meat supply chain framework is to sustain the halal integrity in accordance with Islamic law by eliminating potential food hazards to halal products or services throughout the supply chain [39]. However, non-Muslim consumers are willing to buy halal foods because they perceive that halal foods are safer than non-halal ones [40].

Both halal and tayyib requires the meat industry to consider proper pre-slaughter animal handling, the slaughtering process itself and the production activities that follow the slaughter process. Pre-slaughter handling of animals includes how animals are kept on farms, their transportation, their lairage and how they are restrained, all of which have effects on animal welfare and consequently the quality of the meat [41]. Recently, some research has focused on ways to quantify the impact of pre-slaughter stress and to find approaches to alleviate stress-mediated losses in meat 


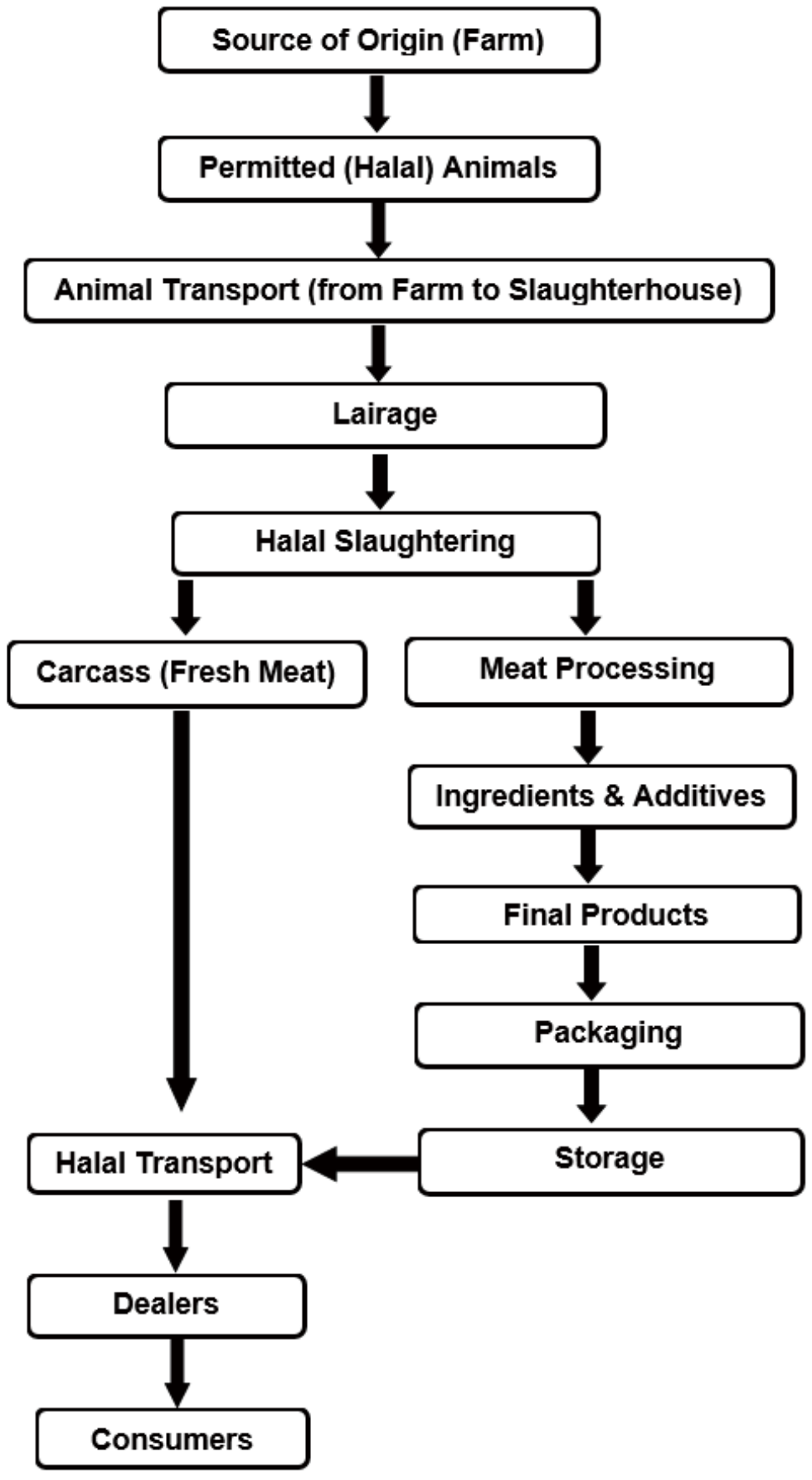

Fig. 3. Simple structure of the halal and tayyib meat supply chain.

quality and meat production [42]. Animal handlers involved in the transportation of animals should be competent enough to understand and manage the species being handled. Dehydration and hunger are the main physical stressors that can occur as a result of long distance transport. Ferguson et al. [41] reported that water deprivation is more severe than food deprivation. Animals must have access to water while in lairage and have the chance to rehydrate after arrival at the abattoir.
It is important to know how animals are handled at slaughter plants [43]. Poor methods of restraint or poor supervision of employees may cause major welfare problems. Animal restraint can be done extremely well if the plant has good equipment, good management and trained employees. Slaughtering can be accurate, quick and efficient with a minimum of distress to the animal when operators put high priority on animal welfare [36]. It has been reported that with all types of slaughtering, proficient and immediate 
bleeding are important parts of the procedure [44]. Removal of blood from the carcass is essential for healthier meat and to extend the meat shelf life.

After slaughter, major cuts of meat (such as those that are lean and low fat) will be transported directly to retailers while the minor cuts (mostly higher fat portions) will often be further processed into new products before distribution to retailors. Tieman [45] stresses the importance of ensuring the halal integrity of fresh meat and meat products during transportation and at the point of consumer purchase. This necessitates the avoidance of direct contact with prohibited (unlawful) foods and the risk of contamination. Today's consumers insist on high-quality meats. Awareness of the connection between diet and health drive this steadily growing demand. Ultimately, consumers and retailers are looking for the same things: quality meat products that last longer and taste fresh.

\section{Consumers' attitude towards purchased meat and meat} products

Red meat is usually sold initially as a whole carcass or in primal cuts. Meat, particularly lean meat, has been recognized to have positive dietary value and is one of the main sources of protein in human diets. Both sensory characteristics and technological aspects, such as color, water holding capacity, cooking losses, and texture, contribute to how consumers make purchasing decisions about meat. The color of meat is one of the most important sensory characteristics because other physical qualities such as texture, taste, or odor are difficult to ascertain at the time of purchase [46]. If the visual appearance of meat is unattractive meat will not be purchased [46]. Consumers prefer to purchase meat that is bright red as an indicator of freshness and wholesomeness rather than brown in color [47]. For the accurate evaluation of meat, color is important not only in meat production but also in situations where color estimation is used as an indicator of meat quality [48].

In the past, consumer preference was more associated with safety, sensory attributes and shelf life. However, in recent times, consumers' preferences are more apt to favor nutrition and health [49]. Furthermore, Haugaard et al. [50] reported a positive assessment by consumers of a new method of preservation for organic meat by using natural preservatives such as herbs and berries that is environmentally friendly. This new technique will minimize the use of chemical additives and salt by creating fresh and interesting taste variations. Vranken et al. [51] documented that the use of chemical substances, such as chemical pesticides, in the cultivation and chemical preservatives that use ingredients with high nitrate and/ or nitrite content added to processed meat products may increase the risk of food poisoning.

\section{Conclusion}

This paper has clearly shown how different areas of the world undertake the slaughter procedure to transform permitted animals into meat that is suitable for human consumption. The methods vary according to spiritual, cultural and commercial needs. Religious slaughter procedure must meet broad rules but may be modified, yet other procedures such as those practiced in developed countries can change. The decision to purchase meat and meat products depends on appearance, taste and concerns about health.

\section{Competing interests}

No potential conflict of interest relevant to this article was reported.

\section{Funding sources}

This manuscript has not received any funding.

\section{Acknowledgements}

Not applicable.

\section{Availability of data and material}

Upon reasonable request, the datasets of this study can be available from the corresponding author.

\section{Authors' contributions}

Writing - original draft: Aghwan ZA.

Writing - review \& editing: Aghwan ZA, Regenstein JM.

\section{Ethics approval and consent to participate}

This article does not require IRB/IACUC approval because there are no human and animal participants.

\section{ORCID}

Zeiad Amjad Aghwan https://orcid.org/0000-0002-7770-4183

Joe Mac Regenstein https://orcid.org/0000-0002-2656-9815

\section{References}

1. Toussaint-Samat M. A history of food. 2nd ed. West sussex, UK: John Wiley \& Sons; 2008.

2. Regenstein JM, Grandin, T. Religious slaughter and animal welfare- an introduction for animal scientists. Proceedings of the 45th Annual Reciprocal Meat Conference. 1992. p. 155-9.

3. Clottey SJA. Manual for the slaughter of small ruminants in developing countries. 1985. http://www.fao.org/docrep/003/ X6552E/X6552E00.HTM. Accessed 23 May 2018.

4. Farouk MM, Al-Mazeedi HM, Sabow AB, Bekhit AE, Adeyemi KD, Sazili AQ, et al. Halal and kosher slaughter meth- 
ods and meat quality: a review. Meat Sci. 2014;98:505-19.

5. Regenstein JM, Chaudry MM, Regenstein CE. The kosher and halal food laws. Compr Rev Food Sci Food saf. 2003;2:111-27.

6. Nakyinsige K, Man YBC, Aghwan ZA, Zulkifli I, Goh YM, Bakar FA, et al. Stunning and animal welfare from Islamic and scientific perspectives. Meat Sci. 2013;95:352-61.

7. Khalid R, Knowles TG, Wotton SB. A comparison of blood loss during the halal slaughter of lambs following traditional religious slaughter without stunning, electric head-only stunning and post-cut electric head-only stunning. Meat Sci. 2015;110:15-23.

8. Nakyinsige K, Fatimah AB, Aghwan ZA, Zulkifli I, Goh YM, Sazili AQ. Bleeding efficiency and meat oxidative stability and microbiological quality of New Zealand white rabbits subjected to halal slaughter without stunning and gas stun-killing. Asian Australas J Anim Sci. 2014;27:406-13.

9. Small AH, McLean D, Owen JS, Ralph JH. Electromagnetic induction of insensibility in animals: a review. Anim Welf. 2013;22:287-90.

10. India curry: what is Jhatka? http://www.indiacurry.com/ faqterms/whatisjhatka.htm. 2015. Accessed 13 Jul 2018.

11. De Smet S. Meat, poultry, and fish composition: strategies for optimizing human intake of essential nutrients. Anim Frontiers. 2012;2:10-6.

12. Aghwan ZA, Sazili AQ, Kadhum KK, Alimon AR, Goh YM, Adeyemi KD. Effects of dietary supplementation of selenium and iodine on growth performance, carcass characteristics and histology of thyroid gland in goats. Anim Sci J. 2016;87:690-6.

13. Leheska JM, Thompson LD, Howe JC, Hentges E, Boyce J, Brooks JC, et al. Effects of conventional and grass-feeding systems on the nutrient composition of beef. J Anim Sci. 2008;86:3575-85.

14. Pena F, Bonvillani A, Freire B, Juarez M, Perea J, Gomez G. Effects of genotype and slaughter weight on the meat quality of Criollo Cordobes and Anglonubian kids produced under extensive feeding conditions. Meat Sci. 2009;83:417-22.

15. Ruusunen M, Puolanne E. Reducing sodium intake from meat products. Meat Sci. 2005;70:531-41.

16. Superior Health Council. Red meat, processed red meats and the prevention of colorectal cancer. 2013. http://www.health. belgium.be/internet2Prd/groups/public/@public/@shc/documents/ie2divers/19091480_en.pdf. Accessed 10 Sep 2018.

17. World Cancer Research Fund/American Institute for Cancer Research. Food, nutrition, physical activity and the prevention of cancer: a global perspective. 2007. http://www.dietandcancerreport.org/index.php. Accessed 10 May 2018.

18. Norat T, Lukanova A, Ferrari P, Riboli E. Meat consumption and colorectal cancer risk: dose-response meta-analysis of epidemiological studies. Int J Cancer. 2002;98:241-56.

19. Cross AJ, Leitzmann MF, Gail MH, Hollenbeck AR, Schatzkin A, Sinha R. A prospective study of red and processed meat intake in relation to cancer risk. PLos Med. 2007;4:e325.

20. Ferlay J, Steliarova-Foucher E, Lortet-Tieulent J, Rosso S, Coebergh JW, Comber H, et al. Cancer incidence and mortality patterns in Europe: estimates for 40 countries in 2012. Eur J Cancer. 2013;49:1374-403.

21. Oostindjer M, Alexander J, Amdam GV, Andersen G, Bryan NS, Chen D, et al. The role of red and processed meat in colorectal cancer development: a perspective. Meat Sci. 2014;97:583-96.

22. De Smet S, Vossen E. Meat: the balance between nutrition and health. A review. Meat Sci. 2016;120:145-56.

23. Department of Standards Malaysia. MS1500:2009: Halal food - production, preparation, handling and storage - General guidelines (second revision). 2009. http://www.jsm.gov.my/ ms-1500-2009-halal-food\#.XOTdwohLiiM. Accessed $10 \mathrm{Jul}$ 2018.

24. Regenstein JM, Grandin T. Kosher and halal animal welfare standards. Institute of Food Technologists Religious and Ethnic Foods Division Newsletter; 2002;5:3-16.

25. Grandin T. Improving religious slaughter practices in the U.S. 2006. http://journals.openedition.org/aof/93. Accessed $13 \mathrm{Jul}$ 2018.

26. Gregory NG. Animal welfare at markets and during transport and slaughter. Meat Sci. 2008;80:2-11.

27. Tieman M, van der Vorst JGAJ, Ghazali MC. Principles in Halal supply chain management. Journal of Islamic Marketing. 2012;3:217-43.

28. Department of Islamic Development Malaysia (JAKIM). Manual procedure for Malaysia halal certification (third revision). 2014. http://www.halal.gov.my/v4/images/pdf/MPPHM2014BI.pdf. Accessed 23 Aug 2018.

29. Humane Slaughter Association (HSA). UK: Slaughter by religious methods. http://www.hsa.org.uk. Accessed 18 Sep 2018.

30. Regenstein JM, Regenstein CE. Current issues in kosher foods. Trends Food Sci Tech. 1991;2:50-44.

31. Gross GA. Knives, shochets (kosher slaughterers). 2011. https://www.flickr.com/photos/news21/6221415954. Accessed 13 Aug 2018.

32. Shechita. 2018. http://en.wikipedia.org/wiki/Shechita\#mw-head. Accessed 18 Jun 2018.

33. Regenstein JM. FDSC 2500 - Kosher and halal food regulations. Course material. Ithaca, NY: Cornell University. 2019.

34. Hubbert WT, Hagstad HV, Spangler E, Hinton MH, Hughes 
KL. Food safety and quality assurance: foods of animal origin. 2nd ed. New Jersey: Wiley-Blackwell; 1996.

35. Aghwan ZA. Ritual and commercial slaughter practices: a main step for meat production and consumption. In: Aghwan ZA, Muhammad J, Awang MD, Nordin FM, editors. Halal practices in economy and community. Kuala Lumpur, Malaysia: Attin Press; 2016. p. 158-176.

36. Aghwan ZA, Bello AU, Abubakar AA, Imlan JC, Sazili AQ. Efficient halal bleeding, animal handling, and welfare: a holistic approach for meat quality. Meat Sci. 2016;121:420-8.

37. Grandin T, Regenstein JM. Religious slaughter and animal welfare: a discussion for meat scientists. Meat Foc Inter. 1994;3:115-23.

38. Velarde A, Rodriguez P, Dalmau A, Fuentes C, Llonch P, von Holleben KV, et al. Religious slaughter: evaluation of current practices in selected countries. Meat Sci. 2014;96:278-87.

39. Aghwan ZAA. Awareness and demand for halal and tayyib meat products supply chain. Proceeding of the 3rd International Seminar on Halalan Thayyiban Products and Services; Bandar Seri Begawan, Brunei Darussalam. 2018. p. 52-8.

40. Hornby C, Yucel S. Halal food going mainstream in Europe: Nestle. 2009. https://www.reuters.com/article/2009/11/17/ idINIndia-44025720091117. Accessed 21 Jul 2018.

41. Ferguson DM, Schreurs NM, Kenyon PR, Jacob RH. Balancing consumer and societal requirements for sheep meat production: An Australasian perspective. Meat Sci. 2014;98:47783.
42. Ferguson DM, Warner RD. Have we underestimated the impact of pre-slaughter stress on meat quality in ruminants? Meat Sci. 2008;80:12-9.

43. Aghwan ZA. Ritual and traditional slaughter practices for meat production. J Islam Soc Econ Devel (JISED). 2019;4:224-30.

44. Helmut P. Bleeding. In: Review of stunning and halal slaughter. 2010. http://www.livecorp.com.au/LC/files/98/98780c7e2e95-4e45-98d9-74ff85c50281.pdf. Accessed 28 Jun 2018.

45. Tieman M. The application of halal in supply chain management: in-depth interviews. J Islamic Mark. 2011;2:186-95.

46. Setser CS. Color: reflections and transmissions. J Food Quality. 1984;6:183-97.

47. Mancini RA, Hunt MC. Current research in meat color. Meat Sci. 2005;71:100-21.

48. Skrlep M, Candek-Potokar M. Pork color measurement as affected by bloom time and measurement location. J Muscle Foods. 2007;18:78-87.

49. Zhang W, Xiao S, Samaraweera H, Lee EJ, Ahn DU. Improving functional value of meat products. Meat Sci. 2010;86:1531.

50. Haugaard P, Hansen F, Jensen M, Grunert KG. Consumer attitudes toward new technique for preserving organic meat using herbs and berries. Meat Sci. 2014;96:126-35.

51. Vranken L, Avermaete T, Petalios D, Mathijs E. Curbing global meat consumption: emerging evidence of a second nutrition transition. Environ Sci Policy. 2014;39:95-106. 